\title{
Developments in Laws on Induced Abortion: 1998-2007
}

By Reed Boland and Laura Katzive

Reed Boland is research associate, Department of Population and International Health, Harvard School of Public Health, Boston, MA, USA, and editor of the Annual Review of Population Law Web site.

Laura Katzive is deputy director, International Legal Program, Center for Reproductive Rights, New York.
CONTEXT: Women's lack of access to legal abortion is a major contributing factor to high rates of worldwide maternal mortality and morbidity. This article describes changes in the legal status of abortion in countries around the world since 1998.

METHODS: The complete texts of new abortion legislation, most often obtained directly from government Web sites, were reviewed to determine changes. Background information was, where possible, also based on a review of complete legal texts. Other sources include the International Digest of Health Legislation (published by the World Health Organization) and Abortion Policies: A Global Review (published in 2002 by the Population Division of the United Nations).

RESULTS: Since 1998, 16 countries have increased the number of grounds on which abortions may be legally performed; in two other countries, state jurisdictions expanded grounds for abortion. Two countries have removed grounds for legal abortion. Other countries maintained existing indications for abortion but adopted changes affecting access to the procedure.

CONCLUSIONS: The worldwide trend toward liberalization of abortion laws observed in 1998 has continued. Recognition of the impact of abortion restrictions on women's human rights has played an increasing role in efforts to provide access to abortion.

International Family Planning Perspectives, 2008, 34(3):110-120
Women around the world seek abortions for similar reasons, ${ }^{1}$ but their ability to terminate a pregnancy legally varies dramatically by where they live. In one country, abortion services may be provided free of charge by the government and available close to home, while in another, providers may face criminal sanctions for offering such services. Where abortion is legally restricted, women are more likely to resort to untrained providers or undergo the procedure in unsanitary conditions. Maternal mortality related to unsafe abortion, therefore, is generally high where abortion is severely restricted. ${ }^{1}$

This article provides an update to a global review of abortion laws by Rahman, Henshaw and Katzive, published in 1998. ${ }^{2}$ It briefly describes abortion laws around the world and discusses all major national legal changes in each region since the previous survey, as well as a number of smaller changes that merit mention. In addition, because international and regional human rights bodies have increasingly addressed abortion as a human rights issue, this article includes a brief discussion of major developments in this area. Finally, the article discusses major trends in global abortion law reform.

Although abortion is a medical procedure, its legal status in many countries has been incorporated in penal codes, which have historically characterized abortion as a crime. Over time, the majority of these criminal bans have been amended to specify circumstances in which abortion carries no legal penalty, such as when a woman's life or health is in danger. Today, most countries, even those with relatively liberal laws on abortion, still have penal code provisions outlining the circumstances in which abortion is a crime. Increasingly, these penal code provisions have been supplemented or replaced by public health statutes, court decisions, and other laws and regulations that address the provision of reproductive health care. Characterizing a country's abortion law, therefore, may require reference to multiple legal sources.

Our analysis of recent changes is based on a review of the complete texts of new abortion legislation, most often obtained directly from government Web sites. Background information was, where possible, also based on a review of complete legal texts. In some cases, translations and other information were obtained from sources such as the International Digest of Health Legislation (published by the World Health Organization); the Annual Review of Population Law Web site; and World Abortion Policies: A Global Review, published in 2002 by the Population Division of the United Nations.

\section{OVERVIEW OF CURRENT LAWS}

Table 1 classifies the abortion laws of 196 countries and dependent territories in categories that show the range of legal restrictions on abortion. ${ }^{3}$ Laws are categorized according to literal readings of statutes, regulations and 
Prohibited altogether or to save the woman's life THE AMERICAS ANDTHE CARIBBEAN

Antigua \& Barbuda, Brazil (R), Chile (ND), Dominica, Dominican

Republic, El Salvador (ND), Guatemala, Haiti,Honduras, Mexico* (F/R),

Nicaragua (ND), Panama (F/R/PA), Paraguay, Suriname, Venezuela

CENTRAL ASIA, THE MIDDLE EAST AND NORTH AFRICA

Afghanistan, Egypt, Iran (F), Iraq, Lebanon, Libya (PA), Oman, Syria (PA/

SA), United Arab Emirates (PA/SA), West Bank \& Gaza Strip, Yemen

EAST AND SOUTH ASIA ANDTHE PACIFIC

Bangladesh, Bhutan (I/R/X), Brunei Darussalam, Indonesia, Kiribati,

Laos, Marshall Islands (U), Micronesia (U), Myanmar, Palau (U), Papua

New Guinea, Philippines, Solomon Islands, Sri Lanka,Tonga,Tuvalu

EUROPE

Andorra, Ireland, Malta, Monaco, San Marino

SUB-SAHARAN AFRICA

Angola, Central African Rep., Congo (Brazzaville), Côte d'Ivoire, Dem. Rep. of Congo, Gabon, Guinea-Bissau, Kenya, Lesotho, Madagascar,

Malawi (SA), Mali (I/R), Mauritania, Mauritius, Nigeria, Sao Tome \&

Principe, Senegal, Somalia, Sudan (R), Tanzania, Uganda

Physical health

THE AMERICAS ANDTHE CARIBBEAN

Argentina (RM), Bahamas, Bolivia (I/R), Costa Rica, Ecuador (RM),

Grenada, Peru, Uruguay (R)

CENTRAL ASIA,THE MIDDLE EAST AND NORTH AFRICA

Jordan, Kuwait (F/PA/SA), Morocco (SA), Qatar (F), Saudi Arabia (PA/SA)

EAST AND SOUTH ASIA ANDTHE PACIFIC

Maldives (SA), Pakistan, Rep. of Korea (F/I/R/SA), Vanuatu

EUROPE

Liechtenstein $(\mathrm{X})$, Poland (F/I/R/PA)

SUB-SAHARAN AFRICA

Benin (F/I/R), Burkina Faso (F/I/R), Burundi, Cameroon (R), Chad (F),

Comoros, Djibouti, Equatorial Guinea (PA/SA), Eritrea (I/R), Ethiopia

(F/I/R/X), Guinea (F/I/R), Mozambique, Niger (F), Rwanda,Togo (F/I/R),

Zimbabwe (F/I/R)

Physical and mental health

THE AMERICAS ANDTHE CARIBBEAN

Colombia (F///R), Jamaica (PA), Saint Kitts \& Nevis, Saint Lucia (I/R),

Trinidad \& Tobago

CENTRAL ASIA,THE MIDDLE EAST AND NORTH AFRICA

Algeria, Israel (F/I/R/X)
Physical and mental health (cont'd.)

EAST AND SOUTH ASIA ANDTHE PACIFIC

Hong Kong (F/l/R), Malaysia, Nauru, New Zealand (F/I), Samoa,

Thailand (F/R)

EUROPE

Northern Ireland, Spain (F/R)

SUB-SAHARAN AFRICA

Botswana (F/l/R), Gambia, Ghana (F/l/R), Liberia (F/l/R), Namibia (F//R), Seychelles (F/I/R), Sierra Leone, Swaziland (F/I/R)

Physical and mental health, and socioeconomic grounds

THE AMERICAS ANDTHE CARIBBEAN

Barbados (F//R/PA), Belize (F), Saint Vincent \& Grenadines (F/I/R)

EAST AND SOUTH ASIA ANDTHE PACIFIC

Australia*, Fiji, India (F/R/PA), Japan (SA), Taiwan (F/I/PA/SA)

EUROPE

Cyprus (F/R), Finland (F/R/X), Iceland (F/I/R/X), Luxembourg (F/R/PA),

Great Britain (F)

SUB-SAHARAN AFRICA

Zambia (F)

Without restriction as to reason

THE AMERICAS ANDTHE CARIBBEAN

Canada (L), Cuba§ (PA), Guyanat, Puerto Rico*†, United States* *† (PA)

CENTRAL ASIA, THE MIDDLE EAST AND NORTH AFRICA

Armenia§, Azerbaijan§, Bahrain§, Georgia§ (PA), Kazakhstan§, Kyrgyz-

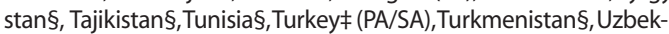
istan§

\section{EAST AND SOUTH ASIA ANDTHE PACIFIC}

Cambodia**,China (SS/L), Dem. People's Rep. of Korea (L), Mongolia§, Nepal§ (SS), Singaporeł‡,Vietnam (L)

EUROPE

Albania§, Austria**, Belarus§, Belgium** ,Bosnia/Herzegovina§ (PA), Bulgaria§, Croatia§ (PA), Czech Rep.§ (PA),Denmark§ (PA), Estonia§, Fmr.Yugoslav Rep. of Macedonia§ (PA), France ${ }^{* *}$, Germany ${ }^{* *}$, Greece§

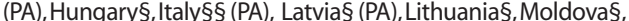
Montenegro§ (PA), Netherlands*†, Norway§ (PA), Portugal‡ (PA), Romania** ${ }^{*}$ Russian Fed.§, Serbia§ (PA), Slovak Rep.§ (PA), Slovenia§ (PA), Swedent†, Switzerland§, Ukraine§

\section{SUB-SAHARAN AFRICA}

Cape Verde§, South Africa§

*Federal system; abortion law determined by states. In Australia and Mexico, state laws fall into different categories of restrictiveness. Classification reflects law affecting largest number of people. †Gestational limit is eight weeks. $\neq$ Gestational limit is 10 weeks. §Gestational limit is 12 weeks. ${ }^{* *}$ Gestational limit is 14 weeks.

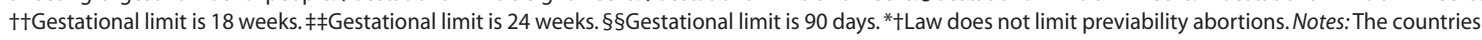
listed include independent states and, where populations exceed one million, semi-autonomous regions, territories and jurisdictions of special status. The table therefore includes Hong Kong, Northern Ireland, Puerto Rico, Taiwan and the West Bank and Gaza Strip. For gestational limits, duration of pregnancy is calculated from the first day of the last menstrual period, which is generally considered to occur two weeks prior to conception. Thus, statutory gestational limits calculated from the date of conception have been extended by two weeks. F=Abortion allowed in cases of fetal impairment. I=Abortion allowed in cases of incest. $\mathrm{R}=\mathrm{Abortion}$ allowed in cases of rape. $\mathrm{RM}=\mathrm{Ab}$ brtion allowed in cases of rape of a mentally disabled woman. $\mathrm{X}=\mathrm{Abortion}$ allowed on additional enumerated grounds relating to such factors as the woman's age or capacity to care for a child. $\mathrm{PA}=$ Parental authorization required. $\mathrm{SA}=\mathrm{Spousal}$ authorization required. $\mathrm{SS}=$ Sex-selective abortion prohibited. $\mathrm{L}=\mathrm{Law}$ does not indicate gestational limit. ND=Existence of defense of necessity is in question. $\mathrm{U}=\mathrm{Law}$ unclear. Source: reference 3

court decisions, as opposed to accounts of how the law is applied in practice. It should be recognized, however, that laws that appear highly restrictive may be interpreted more liberally in practice. By the same token, grounds for legal abortion in some countries may have little practical effect because of a lack of willing abortion providers, the absence of appropriate facilities or severe social stigma attached to ending a pregnancy.

Our classification system, which is described at greater length in the 1998 review, ${ }^{2}$ divides the world's countries into five categories. In the first category are countries whose laws either prohibit abortion entirely or permit it only to save a woman's life. Nearly $26 \%$ of the world's people live in the 68 countries in this category. While some countries in this group explicitly permit abortion to save a woman's life, such as Indonesia, Kenya and Venezuela, others do not. Of countries whose laws make no explicit exceptions, many have longstanding bans on abortion, 
such as Egypt, Haiti and the Philippines. The laws in these countries are generally interpreted in accordance with the general legal principle of "necessity," which provides a defense when an abortion is performed to save a woman's life. It is worth noting, however, that the necessity defense remains largely theoretical in many countries and may not shield providers from prosecution (although it may be presented to block a criminal conviction). Also included in this group are a handful of countries-including Chile, El Salvador and Nicaragua-that previously recognized limited grounds for legal abortion but have recently removed all exceptions from their penal codes, thus calling into question the availability of the necessity defense.

The second category includes countries whose laws permit abortion to protect a woman's physical health. Almost $10 \%$ of the world's people live in the 35 countries in this category, which include Cameroon, Pakistan and Peru. Many of these laws refer to abortion being permitted on "health" or "therapeutic" grounds, and could thus be interpreted broadly, in line with the World Health Organization's definition of health as a "state of complete physical, mental and social well-being and not merely the absence of disease or infirmity." 4 However, given the restrictive stance of many governments toward abortion, when a country's laws make no explicit mention of mental health, we have categorized it as protecting physical health only. In some cases, such laws require that the threatened injury to health be either serious or permanent.

Countries in the third category have laws that explicitly recognize threats to mental health as justification for abortion. Twenty-three countries, representing $4 \%$ of the world's population, have such laws; these countries include Botswana, Israel and Spain. Although abortion on mental health grounds must generally be approved by a medical professional, a number of factors may be taken into consideration to determine whether a pregnancy threatens a woman's mental health. Depending on a woman's background and circumstances, distress over a pregnancy resulting from rape or incest, a diagnosis of a severe fetal impairment or a pregnancy occurring outside of marriage may all be deemed sufficient grounds for an abortion under these laws. ${ }^{5}$

Socioeconomic factors are explicitly recognized as grounds for abortion by countries in the fourth category. Fourteen countries, in which more than $20 \%$ of the world's people live, have laws that permit a medical provider to take a woman's social and economic circumstances into account when determining her eligibility for an abortion. Great Britain, India and Zambia are in this category.

Finally, the fifth category contains laws that permit abortion without restriction as to reason. Fifty-six countries, representing almost $40 \%$ of the world's people, have laws in this category. They include China, France, the Russian Federation and the United States.

As is discussed at greater length in the 1998 review of laws, the number of grounds on which abortion is legal is only one measure of a law's restrictiveness. Laws may limit women's access to the procedure by requiring the authorization of her spouse or guardian, narrowly defining the type of medical personnel who may perform an abortion, limiting the facilities in which the procedure may be provided, prohibiting abortion advertising, requiring a woman to undergo counseling intended to dissuade her from having an abortion or mandating delays between counseling and the procedure. Countries that generally fund medical care may deny funding for abortions deemed medically unnecessary. In addition, laws that permit abortion without restriction as to reason may impose short time limits on when an abortion may be performed without a doctor's authorization.

\section{DEVELOPMENTS SINCE 1998}

Since 1998, 20 countries have made substantial changes in their abortion laws (Table 2). Sixteen countries added indications that moved them from one of our categories to another, or recognized rape, incest or fetal impairment as grounds for legal abortion. In contrast, only two added restrictions that moved them from one category to another. In two countries where abortion laws are made at the state level, significant liberalizations occurred in several states. Other countries (not shown) maintained existing indications for abortion but adopted changes affecting access to the procedure.

\section{The Americas}

- Major changes. Latin America and the Caribbean have seen a number of significant changes since 1998, some that liberalize abortion laws and others that impose restrictions on abortion. The most notable liberalization occurred in Colombia in 2006. The Constitutional Court struck down the country's abortion prohibition on the grounds that its lack of explicit exceptions ${ }^{6}$ failed to respect a woman's rights, including dignity, liberty, health and life. ${ }^{7}$ Abortion is now permitted when a woman's life or health is endangered, as well as in cases of rape, incest or severe fetal impairment. Later in 2006, the Colombian Ministry of Social Protection issued a regulation aimed at ensuring access to legal abortion services, regardless of a woman's ability to pay. Health authorities must guarantee an adequate number of abortion providers and may not cause unnecessary delays in the delivery of services, such as by requiring waiting periods, court approvals or authorization of multiple doctors. ${ }^{8}$

In Saint Lucia, in 2004, as part of a broader reform of the country's penal code, several indications for abortion were recognized. Abortion is now permitted when a pregnancy endangers the woman's life or physical or mental health, or is a result of rape or incest. ${ }^{9}$ Under the former law, abortion was permitted only when performed "for purposes of medical or surgical treatment of a pregnant woman."10

The region has also seen the introduction of the most severe abortion law restrictions in the last 10 years. In 1998, a new penal code came into force in El Salvador that eliminated all exceptions to its prohibition of abortion. ${ }^{11}$ Under the previous law, abortion was permitted to save a 
woman's life and in cases of rape or fetal impairment. ${ }^{12(p .137)}$ In 2006, Nicaragua amended its penal code to eliminate all exceptions to its prohibition of abortion. ${ }^{13}$ The new law removed the provision of the former penal code that allowed therapeutic abortions to be performed after the approval of three physicians and with the consent of the pregnant woman's spouse or nearest relative. ${ }^{14}$

- Other legal developments. In Mexico, where abortion law is determined by the states, several state legislative developments are significant. In 2007, Mexico's Federal District (Mexico City) amended its penal code to permit abortion without restriction as to reason during the first 12 weeks of pregnancy. ${ }^{15}$ This change followed a series of major reforms in the Federal District over seven years. Earlier reforms had expanded grounds for abortion, created procedures for obtaining abortion in cases of rape and involuntary artificial insemination, and required the government to ensure that women could obtain abortions, free of charge, in public health facilities. ${ }^{16,17}$ Providers were granted a limited right to refuse to perform abortions on grounds of conscience, as long as a woman's life or health was not in danger and the provider referred her to a doctor who was not a conscientious objector. The 2007 law built on these reforms by calling for education and outreach on sexual and reproductive health and rights, as well as provision of the full range of safe and effective contraceptive methods. Under the new law, services should be provided with sensitivity to the needs of diverse groups, especially young people and adolescents.

In addition, a number of other Mexican states with restrictive abortion laws, including Chihuahua, ${ }^{18}$ Mexico State, ${ }^{19}$ Morelos, ${ }^{20}$ Baja California Sur ${ }^{21}$ and Hidalgo, ${ }^{22}$ added grounds on which abortion is permitted or not punishable, such as threats to a woman's health and fetal impairment. ${ }^{23}$

Although laws are determined by the state, in 2006, Mexico's federal government issued a directive to all state health ministries, calling on them to ensure that their procedures for obtaining a legally authorized abortion were clearly defined. ${ }^{24}$ This directive was issued following a friendly settlement entered into by Mexico before the InterAmerican Commission on Human Rights in the case of Paulina. Paulina, a 13-year-old girl, was denied an abortion in Baja California after becoming pregnant as a result of rape, an indication for which abortion is legal in that state. The Mexican government, acknowledging that the denial violated Paulina's human rights, agreed to additional provisions, including reparations to Paulina, as well as a regulation in Baja California to ensure access to abortion in cases of rape. ${ }^{25}$

Several other countries in Latin America, while not expanding grounds for legal abortion, put in place procedures aimed at making abortions safer. In 2004, Uruguay's Ministry of Public Health approved an advisory on measures to prevent unsafe abortion that emphasizes the need to provide patients with information that will allow them to make informed and responsible decisions. The strategy includes preabortion consultations where gynecologic and
TABLE 2. Countries that liberalized or restricted their abortion law between January 1998 and December 2007

\begin{tabular}{ll} 
Region & Country \\
\hline Liberalized & Colombia, Mexico (multiple jurisdictions), Saint Lucia \\
The Americas/Caribbean & Iran \\
Central Asia/Middle East/North Africa & $\begin{array}{l}\text { Australia (multiple jurisdictions), Bhutan, Nepal, }{ }^{*} \\
\text { Thailand }\end{array}$ \\
East \& South Asia/Pacific & Portugal, ${ }^{*}$ Switzerland* \\
Europe & Benin, Chad, Ethiopia, Guinea, Mali, Niger, Swaziland, \\
Sub-Saharan Africa & Togo \\
Restricted & El Salvador, Nicaragua \\
The Americas/Caribbean & \\
\hline *Abortion now available without restriction during the first trimester.
\end{tabular}

mental health services are provided, as well as postabortion care. ${ }^{26}$ Ecuador used the enactment of a new health code in 2006 for the same purpose. The code authorizes health services to perform abortions that are legal under the penal code (threat to life or health and pregnancy resulting from the rape of a mentally disabled woman), and prohibits them from refusing to care for women who are in the course of an abortion or who have had a spontaneous abortion, as diagnosed by a professional. ${ }^{27}$ In 2005, in Brazil, which permits abortion only to save the life of the pregnant woman and in cases of pregnancy resulting from rape, the Ministry of Health adopted detailed regulations clarifying for physicians-and for pregnant women-the procedural requirements for performing a legal abortion. ${ }^{28}$

Finally, in a move toward restrictiveness, the United States Supreme Court, in a 2007 ruling, upheld the Partial-Birth Abortion Ban Act of 2003. ${ }^{29}$ Although the law's definition of the nonmedical term "partial-birth abortion" is vague and potentially far-reaching, the Supreme Court interpreted the ban narrowly to apply only to a single second-trimester procedure, intact dilation and evacuation. Weighing Congress's interest in protecting fetal life against women's health for the first time, the Court upheld the ban despite its lack of an exception to safeguard a woman's health.

\section{East and South Asia and the Pacific}

- Major changes. In East and South Asia and the Pacific, all changes liberalized abortion laws.* The most significant reform in this region occurred in Nepal in 2002. Previ-

\footnotetext{
*Because of concern about an imbalance in birthrates between girls and boys, several Asian countries, including China, India and Vietnam, approved laws and regulations in the 1990s to ban the use of ultrasonography and other techniques to identify fetal gender for the purpose of sexselective abortion. In 2002, China, in its Population and Family Planning Law, specified that, in addition to sex determination, the performance of "sex-selective pregnancy termination for nonmedical purposes" was itself prohibited. Although abortion remains available on request, and the law places no associated restrictions or requirements on providers or women seeking abortions, this change does signal the government's continuing concern over the population's growing gender imbalance (source: Population and Family Planning Law, Dec. 29, 2001, art. 35, <http://www. unescap.org/esid/psis/ population/database/poplaws/ law_china/ch_ record052.htm\#chapter5>, accessed Aug. 24, 2008).
} 
ously, although the legal code provided that abortion was a crime "except while doing something for the purpose of welfare," 30 the law was interpreted to prohibit abortion under all circumstances. Abortion law reform came as part of comprehensive legislation aimed at ending discrimination against women in the country's national legal code. Public awareness of the country's high rates of maternal mortality, as well as the fact that women were being imprisoned for having illegal abortions, created pressure on the parliament to liberalize the law. ${ }^{31,32}$ Under the amended legal code, abortion is now permitted at a woman's request during the first 12 weeks of pregnancy, and thereafter in cases of rape or incest or fetal impairment, or if there is a threat to the woman's life or physical or mental health. ${ }^{33}$ The amended legal code bans abortions performed for the purpose of sex selection.

Abortion law reform also occurred in Bhutan, a country that previously lacked a formal law on abortion but was thought to permit only life-saving abortions. ${ }^{12(p .61)}$ In 2004 , as part of a national drive to strengthen democratic institutions and social conditions, ${ }^{34,35}$ Bhutan approved its first penal code, which includes provisions on abortion. Abortion is now permitted in three cases: to save the life of the pregnant woman, when the pregnancy is the result of rape or incest, and when the pregnant woman is of unsound mental condition. ${ }^{36}$

In Thailand, after decades of failed attempts by parliament to relax restrictions on abortion, the Thai Medical Council issued regulations under Thai law that interpret the abortion provisions of the penal code in a manner that increases access to the procedure. ${ }^{37}$ Under the penal code, abortions are allowed in two situations: when "necessary" for the health of the pregnant woman and when the pregnancy is the result of a sexual offense. ${ }^{38}$ Before the issuance of the new regulations, health was usually defined as physical health only, rather than physical and mental health. The regulations make clear that abortions are permitted not only to preserve a woman's physical health, but also to protect her mental health. In addition, threats to mental health include "severe stress" caused by a diagnosis of a serious fetal disability or genetic disease.

- Other legal developments. In 2002, India modified its Medical Termination of Pregnancy Act to remove bureaucratic barriers that restricted access to abortion. ${ }^{39}$ It delegated powers to the local government to approve places for the medical termination of pregnancy, rather than requiring the central government to do so. Abortion remains legal on socioeconomic grounds.

As in Mexico, significant developments occurred in Australia at the state and territory level. Until 1998, abortion was permitted on varying grounds in different states, but in no state was it available on request. ${ }^{40,41}$ This situation changed in 1998 when Western Australia amended its

${ }^{*}$ Although the Portuguese referendum to approve liberalization of the abortion law failed for lack of voter turnout, a clear majority of voters had favored reform. This result was cited as justification for reform by the national parliament (source: reference 50).
Health Act to permit abortions without restriction as to reason through the 20th week of pregnancy, and thereafter in cases of fetal impairment or when there is a threat to the life or health of the woman. ${ }^{42}$ Previously, abortions could be performed "if reasonable" for the preservation of the pregnant woman's life. ${ }^{43}$ In 2002, the Australian Capital Territory went further, removing abortion entirely from its penal code. ${ }^{44}$ Now abortions are legal if performed by a medical practitioner in an approved facility, as provided in the Medical Practitioners (Maternal Health) Act. ${ }^{45}$ Previously, the law was understood to permit abortion to prevent a serious danger to the life or physical or mental health of the pregnant woman, taking into consideration socioeconomic factors. Finally, the state of Tasmania amended its abortion law in 2001 to allow abortions when two registered medical practitioners certify that continuing the pregnancy would involve greater risk of injury to the physical or mental health of the pregnant woman than if the pregnancy were terminated. ${ }^{46}$ In assessing the risk, they may take account of any matter they consider to be relevant. Previously, the law was unclear, although it was generally presumed that some abortions were permitted. ${ }^{47}$

In 2002, the Vietnamese Ministry of Health adopted National Standards and Guidelines for Reproductive Health Care Services. ${ }^{48}$ These guidelines set standards for service delivery, indicating, for example, that vacuum aspiration abortions may be performed by midwives, as well as doctors and assistant doctors. These abortions may be performed at the central level, but also at the provincial and district levels; in the first six weeks of pregnancy, abortions may be performed within the commune, the most local tier of the health system. In addition, the guidelines give detailed information on the use of medication abortion, following up on the country's registration of mifepris-tone earlier that year. ${ }^{49}$

\section{Europe}

- Major changes. While major changes in this region had a liberalizing effect, other legal developments were mixed. Two countries, Portugal ${ }^{50}$ and Switzerland, ${ }^{51}$ reformed their abortion laws significantly, bringing them within the mainstream of abortion laws in the region. Both reforms occurred after national referendums, ${ }^{*}$ following years of advocacy by proponents of reform. In 2007, Portugal made abortion legal without restriction as to reason until the 10th week of pregnancy and thereafter in cases of fetal impairment, when the pregnancy resulted from a crime against sexual freedom or self-determination, or when the pregnancy is a threat to the woman's life or physical or mental health. ${ }^{52}$ Previously, the law permitted abortion only when a woman's life and physical or mental health were in danger and in cases of rape or fetal impairment. ${ }^{53}$ In 2002, Switzerland made abortion legal without restriction as to reason during the first 12 weeks of pregnancy, and thereafter when the pregnancy is a threat to the woman's life or physical or mental health. ${ }^{54}$ Previously, the law permitted abortion only on broad health grounds. ${ }^{55}$ 
- Other legal developments. In 2001, France took steps to make abortion more accessible by extending the gestational period during which abortion is legal without restriction as to reason from 12 weeks to 14 weeks. ${ }^{* 56}$ It also removed a parental consent requirement for minors, requiring instead that minors be accompanied by an adult of their choosing.

Two other Western European countries, Denmark ${ }^{57}$ and Sweden, ${ }^{58}$ amended their laws to increase access to abortion. These countries removed restrictions on the ability of nonresidents to obtain abortions in their countries. Both countries already permitted abortions without restriction as to reason in early pregnancy.

In 2005, Northern Ireland's highest court found that the health ministry had a duty to ensure that medical practitioners and women seeking abortions were adequately informed of the conditions under which abortions could be legally performed. Although guidelines developed by the ministry in response to the judgment have not yet been released, the court's decision is aimed at making abortion more accessible in Northern Ireland. ${ }^{59}$

Abortion restrictions have been adopted in East and Central European countries, but all of these countries remain in the least restrictive category. Since 1998, two countries have placed greater procedural restrictions on women seeking abortions. In Hungary, following a 1998 Constitutional Court decision declaring part of the abortion law unconstitutional, the parliament in 2000 enacted a new law that requires a woman seeking an abortion to undergo two counseling sessions intended to dissuade her from having an abortion and restricts funding for abortion to those performed because of medical indications and in cases of rape ${ }^{60-62}$ Similarly, Latvia approved a new abortion law in $2002^{63}$ and issued new regulations in $2003^{64}$ that require a woman to receive counseling regarding the moral aspects of pregnancy termination, possible medical complications and the possibility of preserving the life of the unborn child. A three-day waiting period follows counseling and during that time, the woman must be "repeatedly" informed of all possible complications resulting from the termination of the pregnancy. An abortion must be performed in an inpatient medical facility and, if the pregnant woman is younger than 16 , she must receive the consent of a parent or guardian.

Finally, a decree issued by the Russian Federation in 2003 restricts the circumstances under which women may legally obtain abortions on social grounds from the end of the 12 th week until the beginning of the 22 nd week of pregnancy. ${ }^{65}$ The decree reduces from 12 to four the number of social conditions under which abortion is legal during this period ${ }^{\dagger}$-when the pregnancy results from rape, when the pregnant woman is incarcerated, when the husband suffers from certain disabilities or dies during the pregnancy, and when the pregnant woman has been deprived of parental rights. Eliminated are indications that are based on the pregnant woman's income, unmarried status, unemployment, refugee status or number of children, among others.

\section{North Africa and the Middle East}

- Major changes. One major development occurred in this region in the last 10 years. In 2005, Iran enacted a law that allows abortions during the first four months of pregnancy in cases of fetal impairment and when a disease endangers the life of the pregnant woman. ${ }^{66}$ This marks the first change in abortion law since a new penal code, based on Islamic law, was enacted following the Revolution of 1989. Under that code, abortions were prohibited with no explicit exceptions. ${ }^{67}$

\section{Sub-Saharan Africa}

- Major changes. In the last 10 years, this region has seen a wave of legislative reform in the area of reproductive health, affecting the abortion laws of six West African francophone countries. The impetus for these changes was a series of regional meetings that brought together legislators, government officials and other interested parties from a number of West African countries. Participants drafted a model law to help legislators address various reproductive health issues. ${ }^{68}$ It codified many of the provisions adopted in 1994 in the Programme of Action of the International Conference on Population and Development (ICPD), as well as other international instruments.

Using this model law as a framework, six countries enacted laws that increase the legal availability of abortion. ${ }^{\ddagger 69}$ Abortion is now legal in Benin, ${ }^{70}$ Guinea $^{71}$ and Togo ${ }^{72}$ when continuance of the pregnancy endangers the life or health of the pregnant woman, when the pregnancy is the result of rape or incest, and when the fetus is affected by a very serious condition. Previously, abortion was considered legal in Benin ${ }^{73}$ and Togo ${ }^{74(p p . ~ 131-132) ~ o n l y ~ t o ~ s a v e ~ a ~}$ woman's life, and in Guinea only to save a woman's life and protect her health. ${ }^{75}$

Chad $^{76}$ and Niger ${ }^{77}$ now also permit abortion to protect a woman's health, but both exclude rape and incest as grounds for abortion. Previously, abortion was considered legal only to save the pregnant woman's life in both countries $^{78,79}$ Finally, in Mali, an abortion may be performed when the pregnancy endangers a woman's life and when the pregnancy is the result of rape or incest. ${ }^{80}$ Previously, abortion was considered legal only to save the life of a pregnant woman. ${ }^{81}$

*Gestational age in French legislation is calculated from the presumed date of conception, two weeks after the first day of a woman's last menstrual period. To be consistent with the descriptions of other laws cited in this article, which consider pregnancy to start at the beginning of a woman's last menstrual period, France's gestational age limit has been extended by two weeks.

tDecree No. 485 of Aug. 11, 2003, voids Decree No. 567 of May 8, 1996, which listed eight additional indications for legal abortion from the end of the 12 th week until the beginning of the 22 nd week of pregnancy.

$\ddagger$ Although Burkina Faso also enacted reproductive health legislation in 2005 that permits abortion when continuance of the pregnancy endangers the life or health of the pregnant woman, when the pregnancy is the result of rape or incest, and when the fetus is affected by a very serious condition at the time of diagnosis, it had already amended its penal code to the same end in 1996. See Burkina Faso, Law No. 049 of Dec. 21, 2005/AN, <http://www.legiburkina.bf/jo/jo2006/no\%5F19/Loi_AN_2005_00021.htm>, accessed June 15,2008. 
Two additional reforms occurred in the region, independent of regional campaigns. In Ethiopia in 2005, a new penal code was adopted to bring criminal law into accord with the democratic principles contained in Ethiopia's new constitution and international conventions that Ethiopia had ratified. ${ }^{82}$ An abortion is now allowed when the pregnancy is the result of rape or incest, when continuance of the pregnancy would endanger the life or health of the pregnant woman, or when the fetus has an incurable and serious impairment. Abortions are also permitted for one limited social reason-when the pregnant woman, owing to a physical or mental infirmity or her status as a minor, lacks the capacity to bring up the child. Previously, abortions were legal only to save the pregnant woman's life or preserve her health or in cases of rape. ${ }^{83}$ In 2005, the Ministry of Health issued guidelines for the implementation of these new penal code provisions. ${ }^{84}$ To ensure abortion access, the guidelines require an abortion to be performed within three days of a request, allow medication abortions and permit midwives and midlevel providers to carry out abortions. They also provide that a minor seeking an abortion need not present proof of age.

Finally, abortion law reform in Swaziland has been brought about, not through the amendment of criminal laws, but in the unusual framework of a new constitution, which was designed, in part, to improve the human rights of women under the law. An abortion may now be performed on therapeutic grounds if a doctor certifies that continued pregnancy will endanger the life of the woman or constitute a serious threat to her physical or mental health, that there is serious risk that the fetus suffers from a physical or mental impairment that would lead to an irreparable and serious disability, that the pregnancy resulted from unlawful sexual intercourse with a mentally disabled woman, or that the pregnancy is the result of rape or incest. ${ }^{85}$ Previously, abortion was governed by unwritten Dutch-Roman common law and generally presumed to be allowed only to save the life of the pregnant woman. ${ }^{74(\mathrm{p} .112)}$ - Other legal developments. In 2004, South Africa amended its Choice on Termination of Pregnancy Act to increase access to abortion. The amendment permits registered nurses, as well as medical practitioners and registered midwives, to perform abortions during the first 12 weeks of pregnancy. ${ }^{86}$ It also decentralizes regulatory authority over abortion facilities, allowing facilities to be approved by provincial officials rather than by the Ministry of Health, and exempting certain facilities from established requirements. Though the amendment was struck down on procedural grounds in 2006, it was readopted in early $2008 .^{87,88}$

\section{International Legal Developments}

Increasingly, international human rights bodies have addressed the impact of abortion restrictions on women's human rights. Although not all conventions and decisions of these bodies have yet been incorporated into national abortion laws, they impose duties on governments to change their laws. The first major development on this front occurred in 2003 when the African Union adopted the Protocol to the African Charter on Human and People's Rights on the Rights of Women in Africa. ${ }^{89}$ Article 14(2) of the protocol provides that "State Parties shall take all appropriate measures to...protect the reproductive rights of women by authorising medical abortion in cases of sexual assault, rape, incest, and where the continued pregnancy endangers the mental and physical health of the mother or the life of the mother or the foetus." As of 2007,21 countries had ratified or acceded to the protocol. Although there are few direct means of forcing countries that have ratified the protocol to implement its provisions, they nonetheless have committed themselves publicly to at least bring their laws into compliance.

In addition, abortion has been the subject of recent major decisions of international legal bodies. In 2005, the United Nations Human Rights Committee held in KL v. $\mathrm{Peru}^{90}$ that the denial of an abortion to a 17-year-old girl carrying an anencephalic fetus violated various rights under the International Covenant on Civil and Political Rights, including the right to be free from inhumane and degrading treatment, the right to privacy and the rights of minors to special protections. ${ }^{91}$ Similarly, in 2007, the European Court of Human Rights ruled that Poland had violated the right to privacy of a pregnant woman under the European Convention on Human Rights by failing to provide her with effective procedures for appealing her physicians' refusal to perform an abortion. ${ }^{92}$ Under Polish law, she should have been entitled to an abortion on health grounds because her pregnancy subjected her to a serious risk of blindness.

\section{DISCUSSION Liberalizing Trend}

The last 10 years have seen a clear trend toward liberalization of abortion laws. This means that more countries have broadened the grounds on which abortion may be performed legally or have adopted measures to make the procedure more accessible. Only a handful of countries have increased restrictions on access to abortion since 1998. Although liberalization of abortion laws and regulations has taken place all over the world, restrictions have increased in the Americas and in East and Central Europe.

The trend toward liberalization of laws should not mask the very real threats to reproductive rights that are present in many parts of the world. Efforts to restrict abortion laws are under way in numerous countries, potentially affecting laws that range from liberal (as in Lithuania ${ }^{93}$ ) to highly restrictive (Dominican Republic ${ }^{94}$ ). Women in many parts of the world are routinely denied services by providers on the grounds of "conscientious objection." 95 Women who have had abortions have faced criminal prosecution, as in El Salvador. ${ }^{96}$ Health care providers have also been prosecuted, as in Kenya, where a doctor and two nurses were jailed for more than a year on murder charges after allegedly performing abortions. ${ }^{97}$ Although the trend to- 
ward liberalization of laws tells us a great deal about many governments' evolving positions on abortion, respect for abortion rights is still far from universal.

\section{Human Rights}

The negative impact of abortion restrictions on women's survival, health and well-being is a growing concern for human rights bodies, as well as nongovernmental human rights advocates. Abortion law reform has occurred against a backdrop of human rights advocacy at the United Nations and in other international, regional and national human rights venues. In some countries, such as Nepal and Swaziland, government reforms of abortion laws have been explicitly motivated by a desire to uphold women's rights. In Colombia, the Constitutional Court was guided by human rights norms in holding that the country's abortion ban was unconstitutional. In Sub-Saharan Africa, abortion law reform has come in the form of reproductive health laws that codify the reproductive rights standards upheld in the 1994 ICPD in Cairo. ${ }^{98}$ For the first time, a regional human rights body, the African Union, has approved a protocol that guarantees the right to abortion under certain circumstances, and two human rights tribunals have directed countries, Peru and Poland, to ensure access to abortion when it is legal under national law.

Those opposed to abortion have also invoked human rights in efforts to amend national constitutions or abortion laws to recognize the right to life of the fetus prior to birth. Such provisions are generally aimed at reinforcing statutory prohibitions against abortion, typically stating that life starts at moment of conception or is protected by the state from that point. Lithuania, for example, has included language protecting fetal interests in its draft law restricting access to abortion.

\section{Measures to Guarantee Access to Abortion}

An important factor in access to abortion is the regulation of facilities that are authorized to provide abortions and the types of medical providers who are allowed to perform the procedure. Even in countries recognizing multiple grounds for abortion, restrictions on facilities and personnel have placed obstacles in the path of women seeking legal abortions. Some countries, including India and South Africa, have decentralized regulatory control over facilities to allow local officials to approve such facilities. Other countries, such as Ethiopia and Vietnam, have used regulations to make clear that midlevel providers can perform abortion or that medication abortion can be provided in public facilities.

Regulations relating to medical technologies may also affect abortion access. Many governments have now approved medications for nonsurgical abortion, thereby broadening the range of abortion methods from which women can choose. At least 39 countries have registered mifepristone, 35 in the last 10 years. ${ }^{49}$ Although Western European countries were among the first to register mifepristone, in recent years, such countries as Tunisia,
India, Hungary and Guyana have approved the drug.

In many countries, access is hampered not by restrictive regulatory procedures, but by the absence of any procedures for obtaining the service. Where laws are restrictive, the lack of regulations makes physicians reluctant to perform any abortions, even those authorized by law, for fear of being subject to prosecution. Most of these laws are contained in penal codes dating from the last century; at the time they were enacted, legislators in all probability thought little about implementation. In Latin America, however, several countries, including Ecuador and Uruguay, have adopted measures that clarify procedures for having an abortion.

Finally, in some countries, such as Thailand, regulations have provided an opportunity to expand previously accepted interpretations of existing laws. By interpreting terms such as "health" to include mental health, these regulations increase the number of women who are eligible for safe abortion in public and private facilities.

\section{CONCLUSION}

The findings of this article and its 1998 predecessor suggest that the trend toward liberalization of abortion laws should be hard to reverse. In a 22-year period, 36 countries have significantly liberalized their abortion laws. An important impetus for many of these changes, particularly over the last 10 years, has been the expansion of the use of human rights principles to support a woman's right to abortion. This basis for reform can only assume greater importance as courts and human rights bodies increasingly hold governments accountable for their duties under human rights law. Women's right to dignity and health entitle them not only to make decisions about abortion, but also entitle them to information, support and access to services. Thus, advocates can call upon governments to expand grounds for legal abortion and to take steps to ensure access to the procedure where it is legal. For governments seeking to meet their obligations under human rights laws, recent progressive developments in abortion laws worldwide may help point the way toward reform.

\section{REFERENCES}

1. The Alan Guttmacher Institute (AGI), Sharing Responsibility: Women, Society and Abortion Worldwide, New York: AGI, 1999.

2. Rahman A, Katzive L and Henshaw S, A global review of laws on induced abortion, 1985-1997, International Family Planning Perspectives, 1998, 24(2):56-64.

3. Center for Reproductive Rights (CRR), The world's abortion laws 2007, poster, New York: CRR, 2007.

4. World Health Organization, Constitution, Jul. 22, 1946, Preamble, <http://www.who.int/governance/eb/who_constitution_en.pdf>, accessed June 15, 2008.

5. Cook RJ et al., Legal abortion for mental health indications, International Journal of Gynecology and Obstetrics, 2006, 95(2):185190

6. Penal Code, promulgated by Law 599 (2000), arts. 122-124.

7. Constitutional Court, Decision C-355/06, May 10, 2006, <http:// 190.24.134.68/relatoria/2006/C-355-06.rtf>, accessed June 15, 2008. 
8. Ministry of Social Protection, Decree No. 4444, 2006, art. 2.

9. Criminal Code (2004), arts. 164-166.

10. Criminal Code (1992), arts. 117-119.

11. Decree No. 1030, Apr. 30, 1997, Book II, Title 1, Chap. 1, arts. 133135.

12. Population Division, United Nations (UN) Department for Economic and Social Development, Abortion Policies: A Global Review, Vol. I: Afghanistan to France, New York: UN, 2001

13. Law No. 603, Oct. 26, 2006, La Gaceta, No. 224, 2006.

14. Penal Code (1974), art. 165

15. Federal District, Decree reforming the Federal District Penal Code and amending the Federal District Health Law, 2007, art. 1, Official Gazette of the Federal District, No. 70, Apr. 26, 2007.

16. Federal District, Decree to reform and add various provisions to the Penal Code and the Code of Criminal Procedure of the Federal District of Mexico, arts. 1 and 2, Aug. 24, 2000, <http://www. reproductiverights.org/pdf/GG_Mexico2000.pdf>, accessed Aug. 21, 2008.

17. Federal District, Decree of Jan. 16, 2004, amending articles 145 and 148 of the New Penal Code for the Federal District and adding articles 16 bis (6) and 16 bis (7) to the Health Law of the Federal District.

18. Chihuahua, Decree No. 690/06, 2006, Official Gazette, No. 103, Dec. 27,2006

19. Mexico State, Decree No. 165, Mar. 17, 2000.

20. Morelos, Decree No. 1221 reforming, amending and repealing various provisions of the Penal Code, Oct. 16, 2000, art. 115.

21. Baja California Sur, Penal Code (2005), art. 252, <http://www. cbcs.gob.mx/marco_juridico/D1525-2.doc>, accessed Aug. 20, 2008.

22. Hidalgo, Penal Code (2008), art. 158, <http://www. ordenjuridico.gob.mx/Estatal/HIDALGO/Codigos/ HGOCOD08.pdf>, accessed Sept. 3, 2008

23. Grupo de Información en Reproducción Elegida, El aborto en los códigos penales de las entidades federativas, May 2008, <http:// www. gire.org.mx/contenido.php?informacion=31>, accessed June 15, 2008.

24. National Center of Gender Equity and Reproductive Health, Secretary of Health, Circular 2192, Apr. 4, 2006, <http://www.gire. org.mx/publica2/OficioCircular_SSA_ILE_2006.pdf>, accessed June 23, 2008.

25. Inter-American Commission on Human Rights, Report No. 21/07, Petition 161-01, Friendly Settlement, Paulina del Carmen Ramírez Jacinto, Mexico, Mar. 9, 2007, <http://www.cidh.org/ annualrep/2007eng/mexicol61.02eng.htm>, accessed June 23, 2008.

26. Ministry of Public Health, Order No. 369, Aug. 6, 2004, $<$ http://www.mednet.org.uy/dml/enlaces/o369.htm>, accessed June 15,2008

27. Public Health Code, Dec. 14, 2006, <http://apps.congreso. gov.ec/sil/documentos/autenticos/152531.doc>, accessed June 15 , 2008.

28. Ministry of Health, Decree No. 1508 on procedures for justification and authorization of pregnancy termination in the national health system in cases permitted by law, Sept. 1, 2005, Official Journal, No. 170, Sept. 2, 2005, <http://dtr200l.saude.gov.br/sas/PORTARIAS/ Port2005/GM/GM-1508.htm>, accessed June 15, 2008

29. Gonzales v. Carhart, U.S. Case No. 05-380, Apr. 18, 2007, <http:// www supremecourtus.gov/opinions/06pdf/05-380.pdf>, accessed June 15, 2008

30. Legal Code (1963), art. 28, Homicide Chapter, Muluki Ain.

31. Center for Reproductive Law and Policy (CRLP) and Forum for Women, Law and Development, Abortion in Nepal: Women Imprisoned, New York: CRLP and Forum for Women, Law and Development, 2002, <http://www.reproductiverights.org/pdf/nepal_2002.pdf>, accessed June 15, 2008.

32. Cohen S, Nepal reforms abortion law to reduce maternal deaths, promote women's status, Guttmacher Report on Public Policy, 2002, <http://www.guttmacher.org/pubs/tgr/05/2/gr050213.html>, accessed June 15, 2008.

33. Legal Code (11th Amendment) Act, 2002, Sept. 26, 2002, <http:// annualreview.law.harvard.edu/population/abortion/NEPAL.abo. htm>, accessed June 15, 2008

34. Taylor \& Francis, The Europa World Year Book 2007, London: Routledge, 2007.

35. U.S. Department of State, Country Reports on Human Rights Practices, 2001, <http://www.bhootan.org/usdept/state_dept_2001. htm>, accessed June 15, 2008

36. Penal Code (2004), arts. 146-147, <http://www.asianlii.org/bt/ legis/laws/pcob2004145/>, accessed June 15, 2008.

37. Thai Medical Council, Regulation on criteria for performing therapeutic termination of pregnancy in accordance with Section 305 of the Criminal Code of Thailand (2005), Government Gazette, Vol. 122, Dec. $15,2005$.

38. Penal Code, art. 305, <http://annualreview.law.harvard.edu/ population/abortion/Thailand.abo.htm>, accessed June 15, 2008.

39. Medical Termination of Pregnancy (Amendment) Act of Dec. 18, 2002, sec. 4, <http://mohfw.nic.in/MTP\%20Act\%20(Amendment) $\% 202002 . h t m>$, accessed June 15, 2008.

40. Cica N, Abortion Law in Australia, 1998, <http://www.aph.gov au/library/pubs/rp/1998-99/99rp01.htm>, accessed June 15, 2008.

41. Drabsch T, Abortion and the Law in New South Wales, 2005 <http://www.parliament.nsw.gov.au/prod/parlment/publications. nsf/9d987d06713c5f544a2565990002alc5/4b0ec8db3b4a730dca257 0610021aa58/\$FILE/Abortion\%20\&\%20index.pdf>, accessed June 15, 2008.

42. Western Australia, Law No. 15, May 26, 1998, <http:// annualreview.law.harvard.edu/population/abortion/WESTERN\%20 AUSTRALIA.abo.htm>, accessed June 15, 1998.

43. Western Australia, Criminal Code Act Compilation, 1913, secs. 199-201.

44. Australian Capital Territory, Crimes (Abolition of Offence of Abortion) Act, 2002, <http://annualreview.law.harvard.edu/ population/abortion/AUSTRALIAN\%20CAPITAL\%20TERRITORY.abo.htm>, accessed June 15, 2008.

45. Australian Capital Territory, Medical Practitioners (Maternal Health) (Amendment) Act, Sept. 9, 2002, <http://annualreview.law. harvard.edu/population/abortion/AUSTRALIAN\%20CAPITAL\%20TER RITORY.abo.htm>, accessed June 15, 2008.

46. Tasmania, Criminal Code (Amendment) Act (No. 2), 2001 $<$ http://www.thelaw.tas.gov.au/tocview/index.w3p;cond=;doc_id= 123\%2B\%2B2001\%2BGS3\%40EN\%2BSESSIONAL;histon=;prompt; rec=;term=>, accessed June 15, 2008

47. Tasmania, Criminal Code Act (1924), art. 134.

48. Ministry of Health (MOH), National Standards and Guidelines for Reproductive Health Services, second ed., Hanoi, Vietnam: MOH, 2004 (available from Ipas Resource Center)

49. Gynuity Health Projects, Mifepristone approval, <http://www. gynuity.org/documents/mife_approval_2007_list.pdf>, accessed June $15,2008$.

50. World briefing: Europe: Portugal: parliament liberalizes abortion, New York Times, Mar. 10, 2007, <http://query.nytimes.com/gst/ fullpage. html? res=9502E3D91331F933A25750C0A9619C8B63\&scp=7 \&sq=portugal+abortion+law\&st=nyt>, accessed June 15, 2008.

51. Olson E, Swiss voters lift restrictions on abortion, New York Times, June 3, 2002, <http:/query.nytimes.com/gst/fullpage.html?res= 9E05E3D $6123 \mathrm{AF} 930 \mathrm{~A} 35755 \mathrm{C0A} 9649 \mathrm{C} 8 \mathrm{~B} 63 \& \mathrm{scp}=4 \& \mathrm{sq}=$ Switzerland+abortion+law\&st=nyt>, accessed June 15, 2008.

52. Law No. 16 of 2007 on exceptions to the criminality of voluntary interruption of pregnancy, Diario da República, pt. 1, No. 75, Apr. 17, 2007.

53. Law No. 6 of 1984 specifying certain exceptional cases where voluntary termination of pregnancy is permissible, Diario da República, 
pt. 1, No. 109, May 11, 1984, translated in International Digest of Health Legislation, 1984, 35(4):768-770.

54. Penal Code, art. 119(2), Amendment of Mar. 23, 2001, adopted by referendum on Sept. 12, 2002.

55. Penal Code (1942), arts. 118-212.

56. Law No. 588 of July 4, 2001, on voluntary interruption of pregnancy and on contraception, Official Journal, No. 156, July 7, 2001, p. 10823.

57. Law on the termination of pregnancy and the law on sterilization and castration as amended by Law No. 435 of June 10, 2003 Lovtidende, pt. A, No. 86, June 11, 2003.

58. Law No. 595 of June 12, 1974, as amended by Law No. 998 of Dec. 4, 2007, <http://www.notisum.se/index2.asp?sTemplate=/template/ index.asp\&iMenuID=331\&iMiddleID=285\&iParentMenuID= 236\& iLanguageID=1>, accessed on August 17, 2008.

59. Family Planning Association of Northern Ireland v. Minister for Health, Social Services and Public Safety, Northern Ireland Law Reports 188 (Ct. App. 2005).

60. Act LXXXVII on the Amendment of Act LXXIX on the protection of foetal life, June 20, 2000, cited in International Helsinki Federation for Human Rights, Women 2000: An Investigation into the Status of Women's Rights in Central and South-Eastern Europe and the Newly Independent States, Nov. 5, 2000, <http://www.ihf-hr.org/ viewbinary/viewdocument.php?download $=1 \&$ doc_id $=2060>$, accessed Aug. 17, 2008

61. CRR, Hungarian government fails to ensure women's human rights, Mar. 22, 2002, <http://www.reproductiverights.org/pr_02_ 0322hungary.html>, accessed June 15, 2008.

62. Katzive L and Rahman A, Central and Eastern Europe: an examination of abortion laws in the global context, 2001, <http:// health.osf.lt/en/archive/2001/abortion_january/martinez_glbl_abrt_ law.htm>, accessed June 15, 2008.

63. Law of Jan. 31, 2002, on sexual and reproductive health, as amended by a Law of Jan. 29, 2004, <http://www.ttc.lv/index. php?\&id $=10 \&$ tid $=50 \& \mathrm{l}=$ EN\&seid $=$ down\& $\&$ itid $=13854>$, accessed June 15, 2008

64. Cabinet Regulation No. 590, Organisational Procedures for the Termination of Pregnancy, Oct. 28, 2003, <http://www.ttc.lv/index. php?\&id=10\&tid=71\&l=EN\&seid=down\&itid=14368>, accessed June 15,2008

65. Decree No. 485 on the list of social indications for induced termination of pregnancy, Aug. 11, 2003

66. Law of June 15, 2005.

67. Law on Islamic Penalties, Law No. 586 of 1991, <http: //annualreview.law.harvard.edu/population/abortion/Iran.abo.htmls, accessed June 15, 2008.

68. Policy Project, Conakry Forum on Promotion of Family Planning through Advocacy and Legislative Reform, A milestone in the FP/RH policy environment in francophone Africa, June 2003, <http://www. policyproject.com/pubs/countryreports/Conakry_ Summary.pdf>, accessed June 15, 2008.

69. Law No. 043 of 1996/ADP amending the Penal Code (1996), arts. 383 and $387,<$ http://annualreview.law.harvard.edu/population/ abortion/BURKINA\%20FASO.abo.htm>, accessed June 15, 2008

70. Law No. 04 of Jan. 24, 2003 on reproductive and sexual health, art.17, <http://annualreview.law.harvard.edu/population/abortion/ BENIN.abo.htm>, accessed June 15, 2008.

71. Law adopting and promulgating the law on reproductive health, July 10, 2000, art. 10, <http://annualreview.law.harvard.edu/ population/abortion/GUINEA.abo.htm>, accessed June 15, 2008.

72. Law No. 005 of Jan. 10, 2007, on reproductive health, art. 42, <http://annualreview.law.harvard.edu/population/abortion/TOGO.abo. htm>, accessed June 15, 2008.

73. Code of Medical Ethics (1973)

74. Population Division, UN Department for Economic and Social Development, Abortion Policies: A Global Review, Vol. III: Oman to
Zimbabwe, New York: UN, 2002

75. Penal Code (1966), art. 269

76. Law No. 06/PR/2002 on the promotion of reproductive health 2002, art. 14, <http://annualreview.law.harvard.edu/population/ abortion/CHAD.abo.htm>, accessed June 15, 2008.

77. Law of May 24, 2006, on reproductive health, <http://www. unfpa.ne/docs/loitypesr.pdf>, accessed June 15, 2008

78. Decree No. 55-1591 of Nov. 28, 1995, concerning the professional code of ethics, art. 38

79. Penal Code (1961), art. 295

80. Law No. 02-44 of June 24, 2002, on reproductive health, art. 13 $<$ http://annualreview.law.harvard.edu/population/abortion/MALI htm>, accessed June 15, 2008

81. Penal Code (1961), art. 176.

82. Proclamation No. 414 of 2004 on the criminal code of the Federal Democratic Republic of Ethiopia, art. 551.

83. Penal Code (1957), art. 534

84. Federal Ministry of Health (FMOH), Technical and procedural guidelines for safe abortion services, Addis Ababa, Ethiopia: FMOH, 2006.

85. Constitution, July 26, 2005, <http://www.gov.sz/>, accessed June 15, 2008.

86. Choice on Termination of Pregnancy Amendment Act, 2004 Government Gazette, No. 27267, Feb. 11, 2005, <http://www. info.gov.za/gazette/acts/2004/a38-04.pdf>, accessed June 10, 2008

87. Constitutional Court, Doctors for Life International v. the Speaker of the National Assembly and Others, Aug. 17, 2006, <http://www constitutionalcourt.org.za/Archimages/7606.PDF>, accessed Aug. 17, 2008

88. Choice on Termination of Pregnancy Amendment Act, 2008 Government Gazette, No. 30790, Feb. 18, 2008, <http://lnw. creamermedia.co.za/articles/attachments/11965_al-08.pdf>, accessed Aug. 17, 2008.

89. African Union, Protocol to the African Charter on Human and People's Rights on the Rights of Women in Africa, 2003, <http://www.achpr.org/ english/_info/women_en.html>, accessed June 15, 2008

90. UN, Human Rights Committee, KL v. Peru, 2005.

91. UN, International covenant on civil and political rights, United Nations Treaties Series, 1976, Vol. 999, p. 171

92. Council of Europe, European Court of Human Rights, Tysiac v. Poland, 2007, <http://cmiskp.echr.coe.int/tkp197/viewhbkm.asp? action $=$ open\&table $=$ F69A27FD8FB86142BF01C1166DEA398649\& key $=61401 \&$ sessionId=961717 \&skin=hudoc-en $\&$ attachment=true $>$, accessed June 15, 2008.

93. Reg. No. XP-432(3), Act of the Republic of Lithuania on the protection of human life in the prenatal stage.

94. CRR, Inter-American Commission issues landmark statement declaring Nicaragua's abortion ban jeopardizes women's human rights, Dec. 1, 2006, <http://www.reproductiverights.org/pr_06_1201IAC Nicaragua.html>, accessed June 15, 2008.

95. Dickens B, Conscientious objection: a shield or a sword? in: McLean SAM, ed., First Do No Harm: Law, Ethics and Healthcare, Aldershot, UK: Ashgate, 2006, pp. 337-351.

96. CRR, Persecuted: Political Process and Abortion Legislation in El Salvador: A Human Rights Analysis, New York: CRR, 2001, <http:// www.reproductiverights.org/pub_bo_perse.html>, accessed on Aug. 17, 2008.

97. CRR and FIDA Kenya, Supplementary Information on Kenya, Scheduled for Review by Human Rights Committee during its 83rd Session, Feb. 27, 2005, 2004

98. UN, Programme of Action of the International Conference on Population and Development, Cairo, Egypt, Sept. 5-13, 1994, U.N Doc. A/CONF.171/13/Rev.1, 1995 


\section{RESUMEN}

Contexto: La falta de acceso de las mujeres al aborto legal es uno de los principales factores que contribuyen a las altas tasas de mortalidad y morbilidad maternas a nivel mundial. Este artículo describe cambios en la situación legal del aborto en paises de todo el mundo a partir de 1998.

Métodos: Se revisó el texto completo de la nueva legislación sobre aborto inducido, la mayoría de las veces obtenida de sitios web gubernamentales, para determinar los cambios. En la medida de lo posible, la información de contexto también se basó en una revisión de textos legales completos. Otras fuentes incluyen el International Digest of Health Legislation (publicado por la Organización Mundial de la Salud) y Abortion Policies: A Global Review (publicada en 2002 por la División de Población de las Naciones Unidas).

Resultados: A partir de 1998, son 16 los países que han aumentado el número de causales por las que el aborto inducido puede ser realizado legalmente; en otros dos países, algunas jurisdicciones estatales expandieron las causales para el aborto. Otros dos países han eliminado causales para el aborto legal. Otros países mantuvieron las indicaciones existentes para el aborto pero adoptaron cambios que afectaron el acceso al procedimiento.

Conclusiones: La tendencia mundial hacia la liberación de las leyes de aborto observada en 1998 ha continuado. El reconocimiento del impacto de las restricciones para el aborto en los derechos humanos de las mujeres ha desempeñado un creciente rol en los esfuerzos para proporcionar el acceso al aborto.

\section{RÉSUMÉ}

Contexte: Le manque d'accès des femmes à l'avortement légal contribue largement aux hauts taux de mortalité et morbidité maternelles enregistrés dans le monde. Cet article décrit les changements venus affecter la légalité de l'avortement dans le monde depuis 1998.

Méthodes: Les textes complets des nouvelles législations relatives à l'avortement, le plus souvent obtenus directement de sites Web gouvernementaux officiels, ont été passés en revue, à la recherche de changements. Dans la mesure du possible, l'information repose aussi sur l'examen des textes légaux complets. Le Recueil international de législation sanitaire (publié par l'OMS) et Abortion Policies: A Global Review (publiée en 2002 par la Division de la population de l'ONU) comptent également au nombre des sources consultées.

Résultats: Depuis 1998, 16 pays ont accru le nombre de raisons licites d'avortement; les juridictions d'État de deux autres ont étendu les motifs admis. Deux pays les ont réduits. D'autres pays encore ont maintenu leurs indications existantes mais adopté des changements affectant l'accès à la procédure.

Conclusions: La tendance mondiale à la libéralisation des lois sur l'avortement observée en 1998 s'est poursuivie. La reconnaissance de l'impact des restrictions de l'avortement sur les droits humains des femmes joue un rôle grandissant dans les efforts d'assurance de l'accès à l'avortement.

Author contact:LKatzive@reprorights.org 